\title{
Discussion on the Construction of Legal System for Chinese Ecological Civilization Construction
}

\author{
Hui Xie \\ Heihe University \\ Heihe, China
}

\begin{abstract}
Fourth Plenary Session of the Eighteenth Central Committee of the CPC demands to speed up establishment and perfection for legal system of ecological civilization and lay a good rule of law foundation of comprehensively promoting ecological civilization construction. This paper carefully analyzes problems of the existing laws in guaranteeing ecological civilization construction and proposes to strengthen legal system construction of ecological civilization and promote process of ecological civilization following international treaties of ecological civilization construction, blending ecological civilization into legal system construction, constructing complete legislation system of ecological civilization.
\end{abstract}

Keywords-ecological civilization; legal system construction

\section{INTRODUCTION}

In the bulletin of Fifth Plenary Session of the Eighteenth Central Committee of the CPC, green development and ecological civilization are listed as top ten objectives for the first time, "beautiful China" is written in the planning for the first time and "green development" is taken as one of five major development concepts; it can be said that 13th FiveYear Plan raises concept of ecological civilization construction to a new history height. It can be seen that, the country will thoroughly solve deteriorating ecosystem, haze, air pollution, degradation of water quality, soil loss, land desertification, vegetation destruction, resource exhaustion and other phenomena should be gradually treated. Facing national strategies of ecological civilization, corresponding, perfect and effective systems must be formulated, while there must be rigid legal system to guarantee implementation of all systems, otherwise, it is very difficult to achieve strategic objectives of ecological civilization as well as main sustainable development strategies.

\section{PROPOSAL AND S YSTEM GUARANTEE OF ECOLOGICAL CIVILIZATION}

\section{A. Proposal of Ecological Civilization}

Since 1990s, international community has been committed to formulating legally binding international instruments and treaties which guarantee ecological civilization so as to protect earth ecosystem we live by. The representative event is Agenda 21 passed in United Nations Conference on Environment and Development held in Rio de

Fund program: The phased objectives of 2013 Heilongjiang general item of philosophy and social science research planning "research on low carbon economic development route of Heilongjiang Province in sight of ecological civilization" (No.: 13B034).
Janeiro, Brazil from June 3 to 14, 1992. This agenda is designed for action blueprint of global sustainable development plan for environmental protection which encouraging development. Although this document is not legally binding, it has a great influence on sustainable development strategies of each national government, whose demonstration effect cannot be overlooked. Prime Minister Li Peng made solemn commitment to perform Agenda 21 and other documents on behalf of the government of China. Sixteenth Executive Meeting of the State Council passed White Paper on China's Population, Environment, and Development in the 21st Century, also called China's Agenda 21 on March 25, 1994, which clarifies total strategies and policies for China's sustainable development, social sustainable development, economic sustainable development, rational utilization of resources and environmental protection and provides medium and long term frame for China's sustainable development. Our country has taken sustainable development as national strategy since 1960, including ecological construction. Chinese Academy of Sciences has continuously released 16 volumes of China Sustainable Development Strategy Report since 1999.

General Secretary $\mathrm{Hu}$ Jintao proposed “ecological civilization" in the national summit meeting on the issues of population, resources and environment in 2005. He pointed out laws and policies system of ecological construction should be perfected and promoted. The Seventeenth Congress of the CPC listed construction of ecological civilization as one objective of building a moderately prosperous society in all aspects and as one strategic task for determination. 1 In October 2008, United Nations Environment Programme took the initiative of developing "green economy", appealed to implement "global green new deal" and realize "green recovery". On September 22, 2009, one of measures to tackle climate change and actively develop low carbon economy and circular economy committed by the government of China in New York United Nations summit on climate change. In October 2010, the Fifth Plenary Session of the Seventeenth Central Committee of the CPC proposed to take "improving ecological civilization level" as important strategic task in "the 12th Five-Year Plan”. Report at 18th CPC National Congress in

\footnotetext{
${ }^{1} \mathrm{Hu}$ Jintao. Hold High the Great Banner of Socialism with Chinese Characteristics and Strive for New Victories in Building a Moderately Prosperous Society in All Respects [N].People's Daily, 2007-10-25( 01)
} 
November 2012 definitely proposed that "construction of ecological civilization is a long-term strategy related to people's well-being and national future." The report specially emphasizes to construct socialism ecological civilization society, and blend it into all aspects and whole process of economic construction, political construction, cultural construction and social construction as well as proposes great historic mission of "beautiful China".

\section{B. System Guarantee of Ecological Civilization}

Ecological civilization shall be guaranteed relying on a series of systems and shall be turned into reality. Our country's cognition for ecological civilization starts from environmental protection. In 1973, our country held the first national environmental protection meeting, which means that environmental protection work in our country officially started. Since sustainable development strategies were implemented in 1996, the government proposes a series of strategies related to green development. Decision of the Central Committee of the Communist Party of China on Some Major Issues Concerning Comprehensively Deepening the Reform passed in the Third Plenary Session of the Eighteenth Central Committee of the CPC in 2013 establishes ecological civilization institutional system for the first time and states composition, reform orientation and key tasks from whole process of source, process and consequences and in accordance with the thinking of "strict prevention for source, strict management for process and severe punishment for consequences". Decision of the Central Committee of the Communist Party of China on Some Major Issues Concerning Comprehensively Promoting Governing the Country by Law passed in Fourth Plenary Session of the Eighteenth Central Committee of the CPC in 2014 stands a new height of governing the country by law and building a socialist country under the rule of law and proposes new requirements for further strengthening legal system construction of ecological civilization in links such as legislation, enforcement, justice and law-abiding and other links.

\section{PROBLEMS OF THE EXISTING LAWS IN GUARANTEEING ECOLOGICAL CIVILIZATION CONSTRUCTION}

Although more complete multi-level and multi-field laws and regulations system has been basically formed in short thirty years, many problems not adapted to current construction ecological civilization still exist from legislation idea, objective and contents, mutual relation and implementation of various laws and regulations.

\section{A. Dislocation of Ecological Legislation Idea}

Currently, ecological legislation protection system in our country is mainly oriented by constitution, based on environmental protection law, dominated by special law and law of natural resources for ecological protection and supplemented by other laws and regulations and rules. Setting idea of this system focuses on economic benefit brought by environmental protection but not ecological benefit, concerns on current environmental renovation but ignores long-term ecological development, even lays particular stress on local environment benefit and abandon overall sustainable development.

Under guidance of this mainstream legislation idea, legal responsibilities provisions of current ecological legal system design in our country lay particular stress on prevention and control of pollution and other public hazard, while protection and improvement of environment is only taken as principle provisions and lacks specific supporting measures and even mutual contradiction exists in contents. 2

\section{B. Loss of Relevant Legal Provisions}

From overall legal system of ecological protection, firstly, the constitution, leading law of system lacks consideration for inner requirements of ecological civilization and does not definitely take sustainable development as guiding ideology of environment and resources protection; environmental right as one of fundamental rights for citizens is also not clarified in the constitution; secondly, from basis of the overall system, basic environmental law is vacant, ecological environmental protection is not main legislation objective of current law of natural resources; Thirdly, laws and regulations are not sound in ecological protection of environmental pollution, special legislation of eco-compensation is deficient, the system provisions are too principled, setting of certain norms lacks rationality and operability, convergence among legal systems is improper.

In view of deficiency for understanding for ecological civilization and improper performance concept, many laws related to environmental protection which shall be issued, such as law on response to climate change, environment conservation act, soil contamination prevention law, nuclear safety law, safe drinking water act, regulations on ground water resource management and water pollution control are not issued all the time, deficiency of legislation in these fields hinders processing of the overall environmental protection.

\section{Poor Ecological Legislation Technology}

Current ecological legislation in our country is mostly lessons learned after real environment accident or absorbs or adopts practices of foreign laws and regulations, which results in that our legislation only lays particular stress on remedy after environmental disaster, but lacks prior monitoring, prevention and correct circumvention and other contents, legislation technology falls behind speed of damage of economic development to environment. The implemented Environmental Protection Law, Law on the Prevention and Control of Atmospheric Pollution, Water Pollution Prevention and Control Law are influenced by one-sided emphasis on GDP and ignoring environmental protection and pollution abatement, and production for ecological civilization construction is insufficient. Although, relevant legislative department has started establishment, revision and revocation of relevant laws, for example, Eighth meeting of the Standing Committee of the Twelfth National People's Congress revised Environmental Protection Law of the

${ }^{2}$ Construction of Legal System of China Ecological Civilization [EB /OL].http: / /www.xjass.com, 2013 - 02 - 01. 
People's Republic of China on April 24, 2014, which comes into effect on January 1, 2015. In Article 1 of environmental protection law, the legislation purpose is to increase promoting ecological civilization construction on the original basis and manifest guiding role of environmental protection law as the fundamental law in environmental protection field, but it is still difficult to meet requirements of ecological civilization construction.

In addition, from overall legal system of environmental protection, ecological norms are scattered as administrative laws and regulations or policies and seen as laws and regulations and policies of each government, and legislation level is low, which causes poor enforcement effect and denser administrative color and lacks legal awe. From current environmental protection law, most are total generality provisions, lacking specific and careful legal rules; so-called punishment measures are only restricted to economic punishment; for majority of enterprises, punishment force fails to reach awe effect. Meanwhile, governance recovery and active construction after accident is very little, the current legislation technology does not conform to requirements of ecological civilization construction seriously.

\section{Inadequate Ecological Enforcement Regulation}

For a long time, radical problems in ecological civilization construction of our country is not merely unsound laws and regulations, problem of slack law enforcement is more serious. Enforcement force for the same law differs in different places and enterprises with different nature. Each administrative organ of government related to environment law enforcement does things in its own way during enforcement. "Collaborators" exist in individual law executor and pollution enterprise, which reflects defect of law enforcement system of environmental protection law in our country and shows severity of the non-observance and lax implementation of laws, and the allowance of lawbreakers in environmental protection field in our country and reflects significance and urgency of legal system construction for ecological civilization in our country.

In recent years, along with strengthening of citizens' rights consciousness and environmental consciousness, environmental disputes emerge endlessly. Since perfect environmental judicature system is deficient in our country currently, citizens' environmental rights and interests cannot be remedied by law in the reality and disputes of environmental rights and interests cannot be settled. Because environmental dispute events involve numerous populations, environmental prosecution will always be triggered, however, a pursuant authoritative law cannot be found in practices, which will cause public interest litigation to lack legal basis.

\section{REASONABLE CONSTRUCTION FOR LEGAL SYSTEM OF ECOLOGICAL CIVILIZATION IN OUR COUNTRY}

Proposal of ecological civilization means that our national government has paid high attention to sustainable development strategies, ecological civilization construction is gradual system engineering; it is a national obligation as well as an international obligation to guarantee sustainable development of ecology. Facing so numerous legal defects, and urgent need for ecological civilization construction, how to construct the legal system conforming to ecological civilization construction becomes a problem in the front of legislators, the author believes that the legal system can be conducted from the following points:

\section{A. Follow International Treaties of Ecological Civilization Construction}

Ecological civilization construction cannot be separated from joint efforts of international community and common abiding by corresponding rules. So far, international conventions related to ecological civilization passed by the United Nations and formally being effective mainly include Convention on Biological Diversity and Framework Convention on Climate Change. As a signatory country of convention, our national government must perform obligations specified by international treaties in principle of adherence to international treaties; in principle of priority of international treaty, if any conflict between domestic law and international treaties, the international treaties shall be preferred; Meanwhile, international treaties shall be declared and known by the countrymen through legal procedures, or during domestic legislation, relevant treaties contents can be transplanted.

\section{B. Blend Ecological Civilization Concept into Legal System Construction}

Legal system of ecological civilization should be established and perfected and become fundamental guarantee of ecological civilization construction. Not only spirit of socialism rule of law should be fully reflected and carried forward, but also ecological civilization concept should be blended into legal system construction. For a long time, large gas exists between implementation effect of environmental law policies and legislation objective. The root cause is that social consensus is not reached between scientific outlook on development and ecological rationality, which is not brought into rule of law process; legal system conforming to ecological rationality and scientific outlook on development are not truly established.3 Therefore, ecological civilization concept must be blended into legal system construction and legal system of ecological civilization conforming to ecological civilization concept must be established. Firstly, ecological overall value should be taken as axiology basis for legal system of ecological civilization. Secondly, ecological civilization core idea of harmonious coexistence between human and nature should be blended into legal system construction of ecological civilization. Thirdly, ecological civilization basic idea of "respect nature, conform to nature and protect nature" should be blended into legal system construction of ecological civilization.

\footnotetext{
${ }^{3}$ Lv Zhongmei. Thoughts on Ruling by Law of Ecological Civilization Construction [J]. Law Science Magazine, 2014( 5) :10 - 21
} 


\section{Construct Complete Ecological Civilization Legislation System}

Ecological civilization proposed definitely proposed in the 17th CPC National Congress is strategic layout from macroscopic angle, targeting at current ecological environmental issues and future development status. Our country should establish guiding ideology of ecological civilization legislation, make a determined effort to start from environment and protect current ecological resources in our country.

Firstly, the first step of ecological civilization legalization is to write ecological civilization into constitution, formulation of ecological civilization should be increased in "foreword" of the constitution; in the Chapter Two of the constitution, "fundamental rights and obligations of the citizens", fundamental rights status for environmental right of the citizens is clarified in addition to political, economic and social cultural rights of the citizens.

Secondly, fundamental law of ecological protection conforming to ecological civilization development concept should be formulated; the overall ecological civilization construction concept should be clarified in the fundamental law in the form of legal system or principle; for the field current legislation technology unable to touch, refer to spirit concept of fundamental law for governing and punishment.

Thirdly, other laws related to ecological environmental protection should be perfected. The legislation idea of department laws related to environmental protection in legal system of our country should also be highly consistent with that of ecological civilization; ecologicalization of legal system should be realized in the whole meaning through specific legal principle and specific legal system of department laws.

Finally, construction of law enforcement system should be strengthened. We must carry out administrate according to law, strictly enforce law and create a better law-enforcing environment of ecological construction; relevant departments should increase training for environmental law enforcement officials in ecology, natural science, environmental protection and other aspects and improve law enforcement force; we should carry out unified power, responsibility, benefit and efficiency and strictly implement accountability system of ecological environment.

\section{REFERENCES}

[1] Cao Mingde. Chinese Environmental Ruling of Law Complying with Ecological Civilization Construction[N]. People's Court Daily, 2011$7-1$

[2] Decision of the Central Committee of the Communist Party of China on Some Major Issues Concerning Comprehensively Promoting Governing the Country by Law[N] Guangming Daily, 2014-10-29( 1).

[3] Cai Shouqiu. On the Legitimacy of China's Ecological Legal System [J]. Legal Forum, 2013 (2) :5 -20.

[4] Chinese Academy of Sciences Sustainable Development Strategies Research Group. China sustainable development Report 2014[M] Beijing: Science Press, 2014. 